\title{
Tidal influences on fish distributions on tropical eastern Pacific rocky shores (Colombia)
}

\author{
Gustavo Adolfo Castellanos-Galindo ${ }^{1,2, *}$, Uwe Krumme ${ }^{1}$, Trevor J. Willis ${ }^{3}$ \\ ${ }^{1}$ Leibniz Center for Tropical Marine Ecology (ZMT), Fahrenheitstr. 6, 28359 Bremen, Germany \\ ${ }^{2}$ Grupo de Investigación en Ecología Animal, Departamento de Biología, Universidad del Valle, A.A. 25360, Cali, Colombia \\ ${ }^{3}$ National Institute of Water and Atmospheric Research Ltd, PO Box 893, Nelson 7040, New Zealand
}

\begin{abstract}
On coasts with high tidal ranges, fishes regularly establish linkages between subtidal and intertidal habitats via tidal movements, such that the home range incorporates habitat that is only intermittently available. To examine the responses of shallow-water reef fish assemblages to tidal water level changes in a macrotidal area of the tropical eastern Pacific, daytime underwater visual fish surveys were carried out in intertidal and subtidal zones at different tidal stages in Utría National Park, Colombia. Labridae and Pomacentridae were the most abundant families, but species within these families changed between intertidal and subtidal zones. Of 106 species, $>70 \%$ used the rocky intertidal zone. Benthic opportunistic reef species comprised ca. $85 \%$ of the intertidal migrant species, whereas the remaining $15 \%$ corresponded to ubiquitous reef and pelagic species. Little variation in subtidal and intertidal fish assemblages was observed between spring and neap tides, but there were large changes detected over the tidal cycle that were attributed to species-specific use of the intertidal zone at high tide. Intertidal fish assemblages comprised a defined subset of species that differed significantly from those of subtidal areas. Rocky intertidal habitats are used only haphazardly by most reef fishes, but a few common species shifted more than $90 \%$ of their population into intertidal habitats during high tide, indicating that for those taxa, intertidal habitats provide important foraging opportunities. This may introduce a significant source of local-scale bias to density estimates of subtidal reef fishes, and reef fish monitoring programmes should specifically factor tidal state as a controlling influence in macrotidal areas.
\end{abstract}

KEY WORDS: Tidal migrations · Rocky intertidal · Reef fishes · Tropical eastern Pacific · Utría Resale or republication not permitted without written consent of the publisher

\section{INTRODUCTION}

Coastal shallow-water organisms show multiple movement patterns varying in space and time throughout their life cycles. Home range movements, defined as those undertaken by organisms routinely to feed, rest or defend a territory, constitute a significant part of these patterns. Two short-term cycles may influence coastal organisms' home range movements: tides and light intensity changes (Gibson 1992, Palmer 2000, Pittman \& McAlpine 2003, Tolimieri et al. 2009). Although widely recognised as a force affecting coastal organisms, tides are often neglected in studies aimed at identifying processes responsible for spatial changes in coastal shallow-water community distribution (Gibson 1999).
Intertidal migrations by many fish species have been directly and indirectly demonstrated in different systems, such as temperate sandy beaches (e.g. Ansell \& Gibson 1990, Burrows et al. 1994), rocky shores (Rangeley \& Kramer 1995, Faria \& Almada 2006), salt marshes (Kneib 1997, Laffaille et al. 2000), tropical seagrasses (Robertson 1980, Dorenbosch et al. 2004) and mangroves (Krumme et al. 2004). Apart from intertidal migrations, fishes may use tides to move within and between habitats (Gibson 2003). Their tidal movements can either be considered migrations (sensu Dingle 1996) or opportunistic movements within a home range (Pittman \& McAlpine 2003). Unsworth et al. (2007) found no clear patterns in reef fish responses to tidal variability in an area of Sulawesi (Indonesia) with 
maximum tidal amplitude of $2.3 \mathrm{~m}$. On the other hand, on reefs of Tulear (Madagascar), an area with semidiurnal tides and tidal ranges between 2 and $4 \mathrm{~m}$, Vivien (1973) found that the fish response to daily tidal variability was species-specific, with groups of species that apparently did not show any response to tides and some other groups moving from deeper reef to inner reef zones at high tide. The varying results suggest the need for a more comprehensive understanding of the influence of tides on reef fish distribution in meso- and macrotidal areas of the world.

The ecological functions of fish intertidal migrations are commonly linked with benefits associated with increased food availability and a reduction in predation risk (Norton \& Cook 1999, Gibson 2003). These benefits, however, may vary among different intertidal systems (i.e. mangroves, seagrasses and rocky shores). For example, on sandy beaches and rocky shores, resources are concentrated around lower intertidal levels (Lubchenco et al. 1984, Ansell \& Gibson 1990), whereas in mangrove forests, resources are concentrated around the above-ground root system at higher intertidal levels (Koch 1999). Sheaves (2005) suggested that due to the presence of abundant benthic prey and structural complexity, mangrove intertidal areas are unique habitats in which juvenile fish abundance and species richness are greater than in other shallowwater habitats.

The tropical eastern Pacific (TEP) is predominantly a meso- and macro-tidal (range 2 to $>6 \mathrm{~m}$ ) region where fish responses to tidal fluctuations have been poorly investigated. Most reef fish monitoring methodologies in the area (e.g. Garzón-Ferreira et al. 2002) do not acknowledge the potential bias on density estimates that may arise from sampling at different tidal stages. This may confound comparisons between sites and may considerably reduce the statistical power of between-treatment comparisons (Willis et al. 2006). Estimating the short-term temporal variability induced by tides in reef fish assemblages will help to better account for this potential systematic bias in experimental and monitoring studies.

Tidal influences on fish assemblages may arise from 2 sources of variability: the instantaneous effect of tidal state that controls the accessibility of intertidal habitats (flood, high, ebb and low tide) and the amplitude of the tidal range (i.e. spring versus neap tides) that controls the accessibility of higher shore habitats.

We aimed to identify the importance of tidal water level changes in reef fish distribution, and at the same time characterise the role that rocky intertidal areas might have as temporarily accessible habitats. Five specific questions were posed: (1) What is the fish species composition in rocky intertidal and subtidal habitats at 4 sites on the Colombian Pacific coast?
(2) Are there differences in the structure of the fish assemblages in intertidal or subtidal zones over spring/neap cycles (tidal amplitude)? (3) Are there variations in the structure of subtidal fish assemblages over tidal stages (low, flood, high and ebb tide)? (4) At high tide, are there differences in the structure of fish assemblages between the rocky subtidal and the intertidal zones? (5) If significant variation with tidal state and/or amplitude is found, which species utilise intertidal habitats, and how important are these habitats to the local assemblage?

\section{MATERIALS AND METHODS}

Study area. The TEP, extending from ca. $25^{\circ} \mathrm{N}$ to ca. $4^{\circ} \mathrm{S}$ (Robertson \& Cramer 2009), is considered the most isolated marine biogeographic province of the world (Robertson et al. 2004). This isolation is due to the emergence of the Isthmus of Panama 3.1 myr ago (Coates \& Obando 1996) and a 5000 to $7000 \mathrm{~km}$ uninterrupted deep-water gap that has separated the province from the western and central Pacific for the past 65 myr (Grigg \& Hey 1992). The continental shelf along the province's coastline is very narrow with a mosaic of estuaries, mangrove forests, sandy beaches and rocky shores with few coral reef areas (Glynn \& Ault 2000).

Utría is a national protected area in the Colombian Pacific $\left(5^{\circ} 53^{\prime}\right.$ to $6^{\circ} 11^{\prime} \mathrm{N}, 77^{\circ} 9^{\prime}$ to $\left.77^{\circ} 24^{\prime} \mathrm{W}\right)$ that includes 15000 ha of seabed. The most conspicuous geological feature within the park is the Utría Sound, which is $4 \mathrm{~km}$ long and $800 \mathrm{~m}$ wide at low tide with a south-north orientation and average depth of $30 \mathrm{~m}$ (Fig. 1). Rocky intertidal and subtidal shorelines constitute the predominant seascape of the park. Rains occur throughout the year with a small decrease during December to April (annual precipitation: ca. $7 \mathrm{~m}$ ). Tides are semi-diurnal with tidal ranges of ca. 2 to $3 \mathrm{~m}$ at neap and 3 to $>4 \mathrm{~m}$ at spring tides, with flood and ebb tides being symmetrical.

Sampling design. During a preliminary field trip to Utría National Park in September 2007, several sites in the inner and outer part of the sound were visited. Four sites were selected according to a qualitative assessment of similarities in intertidal and subtidal areas (depths, slopes, inundated intertidal areas, substratum cover; Fig. 1).

In a subsequent field trip in November, 9 permanent $25 \times 2 \mathrm{~m}$ transects at each of the 4 selected sites were established at neap tide and marked with painted stones (36 transects in total). Three transects were located at medium intertidal, low intertidal and subtidal zones using mean emersion time as a proxy of the transect's intertidal height. Slack high and low water corresponded accurately to the tide tables from the 


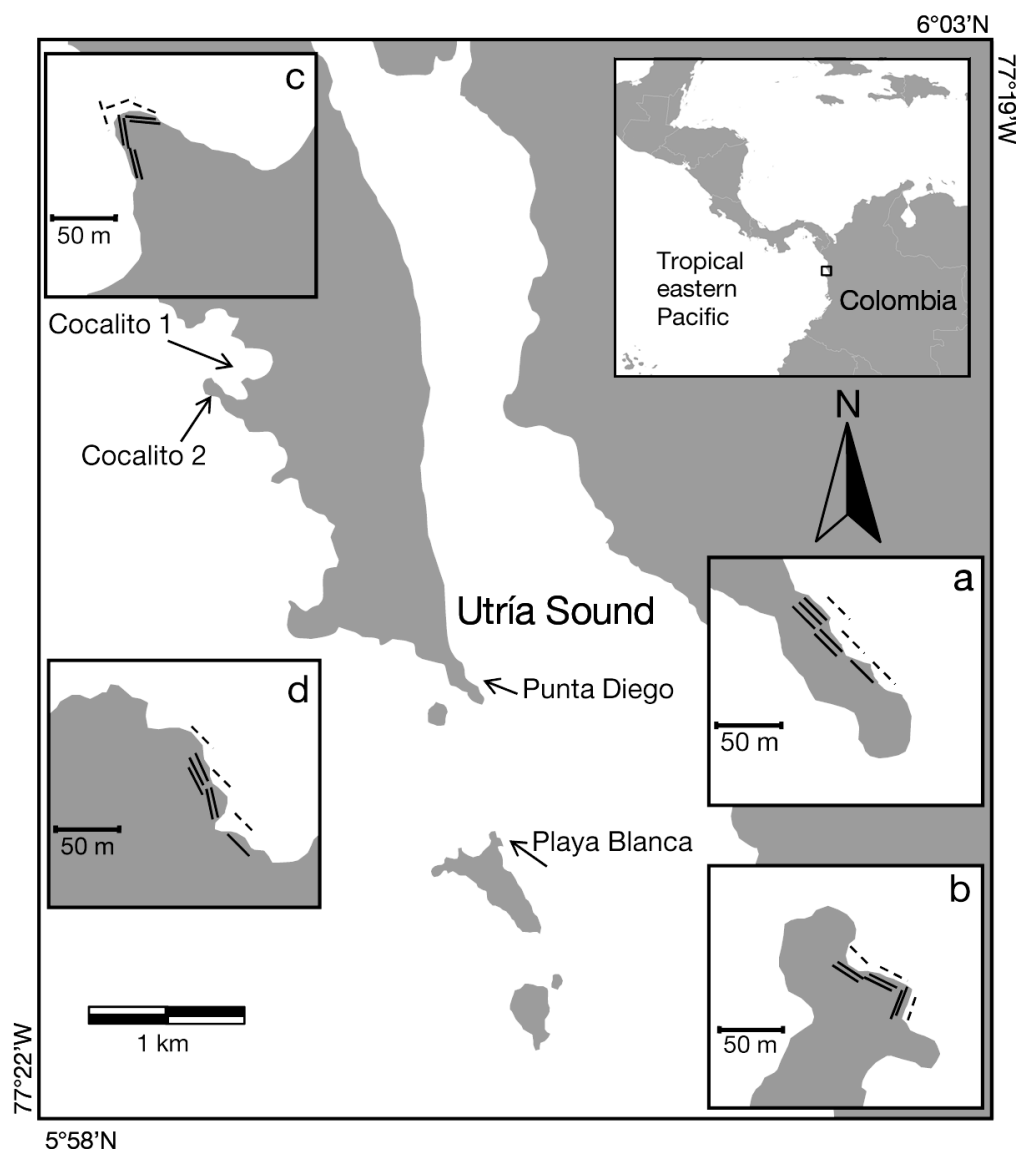

Fig. 1. Utría Sound, showing its position within the tropical eastern Pacific. Location of intertidal (continuous lines) and subtidal transects (dashed lines) is indicated for each site: (a) Punta Diego; (b) Playa Blanca; (c) Cocalito $1 ;$ (d) Cocalito 2

nearest point (Bahía Solano; IDEAM 2006, 2007). Low intertidal transects were established in zones that could be surveyed $3 \mathrm{~h}$ after slack low tide; medium intertidal transects were submerged $1 \mathrm{~h}$ before slack high water ( $>1 \mathrm{~m}$ water depth). Subtidal transects were established at water depths $<3 \mathrm{~m}$ at low tide. Replicate transects at the 4 sites were chosen, attempting to be as similar as possible in substratum cover to avoid confounding effects of this factor.

From November to December 2007 and from the end of January to the beginning of March 2008, weekly underwater visual censuses (UVCs) were made at the 4 sites $\left(1\right.$ site $\left.\mathrm{d}^{-1}\right)$ in the previously defined strip transects using snorkelling gear. Fish observations were made during most of the daylight tidal cycle covering low water, flood, ebb and high water periods. Sampling time during the week was selected according to the days with the greatest or lowest tidal amplitude during spring or neap tide periods, respectively (1 or $2 \mathrm{~d}$ after each lunar phase). Due to the time delay of the tidal cycle with respect to the diel cycle, slack high water occurred between 9:00 and 11:00 $\mathrm{h}$ at neap and between 15:00 and 17:00 $\mathrm{h}$ at spring tides. Slack low water occurred between 15:00 and 17:00 $\mathrm{h}$ at neap and between 9:00 and 11:00 $\mathrm{h}$ at spring tides. Counts were restricted to when water transparency was $>3 \mathrm{~m}$. Reduced visibility was infrequent and occurred only when heavy rains preceded censuses or when material was suspended at some spring tidal stages.

Data treatment. We used permutational multivariate analysis of variance (PERMANOVA, Anderson 2001) to test hypotheses about differences in fish assemblages between sites, depth zones (intertidal versus subtidal), tidal stage (low water, flood, high water and ebb) and tidal amplitude (spring versus neap). This 'semi-metric MANOVA' constructs an analogue Fisher's F-test statistic based on any measure of dissimilarity and obtains $\mathrm{p}$ values using permutations. PERMANOVA, like analysis of similarities (ANOSIM) and other similar multivariate tests, may be sensitive to differences in the dispersion of points (analogous to heterogeneity of variance in univariate tests). Hence, the routine PERMDISP (a test of homogeneity of multivariate dispersion, analogous to the univariate Levene's test) was used to check that statistically significant differences between groups detected with PERMANOVA were not an artefact of differences in dispersion among groups (Anderson 2006, Anderson et al. 2008).

To visualise multivariate patterns revealed by PERMANOVA, we used a combination of unconstrained and constrained ordination techniques: principal coordinate analysis (PCO, a parametric analogue of multidimensional scaling; principle component analysis is a form of PCO that uses Euclidean distance as the distance measure) and canonical analysis of principal coordinates (CAP, Anderson \& Willis 2003). CAP is a form of canonical discriminant analysis, based on any distance measure, that uses PCO axes to search for the vectors in multivariate space that maximise the differences among a priori defined groups. The species responsible for any differences were then identified based on the strength of their correlation with the canonical discriminant axes. All multivariate analyses were done using the PERMANOVA+ for PRIMER software (Anderson et al. 2008). The identities of species responsible for patterns were determined using correlations of the individual species variables with the PCO or CAP axes of the ordinations (Anderson \& Willis 2003). All multivariate analyses were based on Bray-Curtis distances calculated from squareroot transformed data. 
The 5 questions posed in the Introduction were addressed as follows.

Question 1: Site and depth zone differences were determined using a combination of descriptive statistics and CAP.

Question 2: The effects of tidal amplitude (neap versus spring tides) on fish assemblages in subtidal and intertidal habitats could not be tested using data collected over all 4 tidal stages, since intertidal data cannot be collected at low tide. Therefore, the effect of tidal amplitude was tested using data collected during flood tide, high tide and ebb tide. Separate tests were done for intertidal and subtidal zones, because of large compositional differences in fish assemblages between the 2 zones (see Results). PERMANOVA analyses were conducted on square-root transformed data, treating the factor Site as a random effect. CAP was also used to examine differences in spring and neap tide data.

Question 3: Variation in the structure of fish assemblages with tidal stage was examined using a Site (4 levels; random) $\times$ Stage (4 levels: low water, flood, high water and ebb tide; fixed) model on subtidal transect data with the spring and neap tide data pooled. Since sites varied considerably in their composition, individual CAPs for tidal stage were performed for each site to observe in more detail the differences between tidal stages.

Question 4: Subtidal fish assemblages were compared to intertidal assemblages using a combination of PERMANOVA and CAP conducted on high tide data. The PERMANOVA was a 2-way mixed model testing the effects of site (random effect) and zone (fixed effect). CAP was used to visualise differences between 8 groups (4 sites $\times 2$ zones). Species responsible for differences along the CAP axes were determined as above, with those species having a frequency of occurrence $>0.2$ and correlations $>0.4$ considered to have made a significant contribution to the separation of groups (Anderson \& Willis 2003).

Question 5: To determine the effects of tidal stage on counts of key fish species (identified from the CAP analysis of sites $\times$ zones), we used a generalised linear model to estimate differences in density of subtidal counts at high and low tide. Since count data are generally overdispersed and have heterogeneous variances (i.e. the standard deviation tends to increase with the mean), the data were modelled using a loglinear model structure assuming a Poisson distribution. These models express the counts, $Y$, as

$$
Y \sim \operatorname{Poisson}(\lambda)
$$

where Poisson $(\lambda)$ denotes a (possibly overdispersed) Poisson distribution with expected value of $\lambda$, and $\log (\lambda)$ is modelled as a linear function of the effects. For example, the count of a species in replicate $j$ at site $i$ and depth $k$ is modelled by

$$
\log \left(\lambda_{i j k}\right)=\alpha_{i}+\beta_{k}
$$

where $\alpha$ and $\beta$ denote effects due to site and depth, respectively. The right-hand side of this equation can be modified to include any interactions of interest. Log-linear model analyses were conducted using SAS.

\section{RESULTS}

\section{Fish assemblage composition (Question 1)}

We counted a total of 66846 fishes from 106 species and 41 families in 661 transect observations (intertidal and subtidal). Nine families accounted for $52 \%$ of the total number of species: Carangidae, Haemulidae, Labridae, Lutjanidae, Muraenidae, Pomacentridae, Scaridae, Serranidae and Tetraodontidae. The most abundant species were Thalassoma lucasanum, Stegastes acapulcoensis and Chromis atrilobata, representing $48 \%$ of all the fishes counted.

In 299 transects completed in intertidal areas, a total of 17836 fishes were counted, and 73 species grouped in 30 families were observed. Pomacentridae and Labridae were the most important families in number of species and individuals. Thalassoma lucasanum, Stegastes acapulcoensis and Halichoeres notospilus accounted for most of the individuals (19, 18 and 16\%, respectively). Another 3 pomacentrids (Abudefduf concolor, A. troschelii and Microspathodon bairdii) were also abundant (Table 1).

Benthic reef species were found to be the most important component of the intertidal fish assemblage, accounting for ca. $85 \%$ of the total abundance. The remaining $15 \%$ contained reef ubiquitous and pelagic species from the Kyphosidae (Kyphosus elegans and $K$. analogus), Mugilidae (Chaenomugil proboscideus and Mugil curema), Carangidae (Caranx caninus and C. sexfasciatus), Belonidae (Tylosurus pacificus and T. crocodilus fodiator) and Lutjanidae (Lutjanus spp.). Although individual size was not recorded during censuses, intertidal reef ubiquitous and pelagic species were generally larger than intertidal benthic reef species.

Twenty-seven species were found at all 4 intertidal sites sampled, indicating their status as regular visitors. In contrast, 30 species were seldom found in these intertidal sites (<10 individuals) having low frequency of occurrence, and can be considered as accidental visitors (Table 1). Other species were abundant in the intertidal areas at single sites (i.e. Caranx sexfasciatus and Tylosurus pacificus), suggesting site preferences of these species. 
Table 1. Relative abundance (RA, \%), mean densities (ind. $50 \mathrm{~m}^{-2}$ ) and frequency of occurrence (F) at intertidal and subtidal areas of the most representative fish species. Species are sorted by their RA \% in the intertidal area. Species categories are as described in the 'Discussion': ${ }^{1}$ opportunistic reef species; ${ }^{2}$ mid-water species; ${ }^{3}$ permanent reef species; ${ }^{5}$ no response to tides; ${ }^{6}$ intertidal resident species. The 10 most abundant species in the whole assemblage (intertidal and subtidal) are shown in bold. Other less abundant taxa in decreasing abundance: Malacoctenus sp. ${ }^{6}$, Tylosurus pacificus, Cirrhitus rivulatus, Scarus ghobban, Tylosurus crocodilus fodiator, Sufflamen verres, Caranx caballus, Lutjanus novemfasciatus, Chaetodon humeralis, Acanthurus xanthopterus, Bodianus diplotaenia, Mulloidichthys dentatus, Kyphosus analogus, Prionurus laticlavius, Scarus rubroviolaceus, Lutjanus aratus, Diodon hystrix, Scarus perrico, Scarus compressus, Gymnomuraena zebra, Halichoeres dispilus, Myripristis leiognathus, Ostracion meleagris meleagris, Pseudobalistes naufragium, Arothron hispidus, Axoclinus lucillae, Fistularia commersonii, Rypticus bicolor, Zanclus cornutus, Echidna nebulosa, Hypsoblennius brevipinnis, Muraena lentiginosa, Pomacanthus zonipectus, Acanthemblemaria hancocki, Aetobatus narinari, Scorpaena mystes, Seriola rivoliana, Anisotremus caesius, Canthigaster cf. janthinoptera, Coralliozetus springeri, Diodon holocanthus, Echidna nocturna, Gerres simillimus, Mycteroperca xenarcha

\begin{tabular}{|c|c|c|c|c|c|c|}
\hline \multirow{2}{*}{ Species } & \multirow{2}{*}{ RA \% } & \multirow{2}{*}{$\begin{array}{l}\text { - Subtidal } \\
\text { Density } \pm \text { SE }\end{array}$} & \multirow[b]{2}{*}{$\mathrm{F}(\%)$} & \multirow{2}{*}{ RA \% } & \multirow{2}{*}{$\begin{array}{l}\text { - Intertidal- } \\
\text { Density } \pm \text { SE }\end{array}$} & \multirow[b]{2}{*}{$\mathrm{F}(\%)$} \\
\hline & & & & & & \\
\hline Thalassoma lucasanum $^{1}$ & 21.32 & $26.14 \pm 1.30$ & 94.99 & 18.50 & $9.79 \pm 1.09$ & 41.78 \\
\hline Stegastes acapulcoensis $^{3}$ & 15.94 & $20.43 \pm 0.54$ & 99.25 & 17.54 & $9.52 \pm 0.47$ & 92.06 \\
\hline Halichoeres notospilus ${ }^{3}$ & 2.23 & $3.12 \pm 0.23$ & 74.46 & 16.42 & $8.95 \pm 0.33$ & 95.94 \\
\hline Abudefduf troscheliii ${ }^{3}$ & 2.07 & $3.02 \pm 0.26$ & 55.99 & 8.77 & $5.12 \pm 0.64$ & 58.46 \\
\hline Abudefduf concolor ${ }^{3}$ & 0.65 & $0.92 \pm 0.11$ & 35.78 & 6.98 & $3.89 \pm 0.17$ & 92.46 \\
\hline Microspathodon bairdii ${ }^{3}$ & 0.29 & $0.48 \pm 0.08$ & 19.27 & 4.66 & $2.94 \pm 0.15$ & 80.84 \\
\hline Chaenomugil proboscideus ${ }^{2}$ & 0.04 & $0.09 \pm 0.06$ & 1.37 & 4.60 & $3.22 \pm 0.59$ & 17.60 \\
\hline Kyphosus elegans $^{2}$ & 2.98 & $4.19 \pm 1.25$ & 23.60 & 4.42 & $3.17 \pm 0.65$ & 45.19 \\
\hline Ophioblennius steindachneri ${ }^{1}$ & 1.28 & $1.80 \pm 0.12$ & 68.68 & 3.54 & $1.95 \pm 0.20$ & 42.11 \\
\hline Mugil curema ${ }^{2}$ & 0.19 & $0.37 \pm 0.10$ & 6.94 & 2.47 & $1.73 \pm 0.30$ & 17.92 \\
\hline Caranx sexfasciatus $^{2}$ & 1.85 & $3.29 \pm 0.70$ & 11.80 & 1.70 & $1.64 \pm 0.51$ & 10.69 \\
\hline 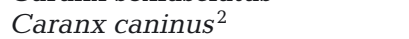 & 0.49 & $0.89 \pm 0.29$ & 5.20 & 1.32 & $0.80 \pm 0.31$ & 8.05 \\
\hline Microspathodon dorsalis ${ }^{1}$ & 3.64 & $4.63 \pm 0.38$ & 60.69 & 1.13 & $0.73 \pm 0.11$ & 23.68 \\
\hline Holacanthus passer ${ }^{1}$ & 0.96 & $1.37 \pm 0.08$ & 61.65 & 0.91 & $0.59 \pm 0.05$ & 31.73 \\
\hline Chromis atrilobata ${ }^{5}$ & 18.81 & $25.05 \pm 2.03$ & 48.84 & 0.84 & $0.57 \pm 0.27$ & 2.42 \\
\hline Lutjanus argentiventris $^{2}$ & 0.59 & $0.90 \pm 0.08$ & 42.62 & 0.55 & $0.40 \pm 0.05$ & 28.07 \\
\hline Johnrandallia nigrirostris 1 & 0.77 & $1.19 \pm 0.08$ & 53.55 & 0.53 & $0.37 \pm 0.04$ & 26.93 \\
\hline Plagiotremus azaleus ${ }^{1}$ & 0.47 & $0.70 \pm 0.06$ & 35.35 & 0.38 & $0.27 \pm 0.04$ & 16.37 \\
\hline Arothron meleagris ${ }^{1}$ & 0.34 & $0.58 \pm 0.04$ & 39.10 & 0.37 & $0.27 \pm 0.03$ & 19.94 \\
\hline Stegastes flavilatus ${ }^{1}$ & 2.69 & $3.68 \pm 0.21$ & 72.69 & 0.36 & $0.29 \pm 0.05$ & 18.60 \\
\hline Canthigaster punctatissima $^{1}$ & 5.01 & $6.19 \pm 0.33$ & 85.95 & 0.35 & $0.31 \pm 0.04$ & 21.24 \\
\hline Sargocentron suborbitalis ${ }^{1}$ & 1.22 & $1.60 \pm 0.17$ & 40.40 & 0.35 & $0.28 \pm 0.05$ & 16.62 \\
\hline Epinephelus labriformis ${ }^{1}$ & 0.86 & $1.24 \pm 0.07$ & 59.09 & 0.23 & $0.21 \pm 0.03$ & 16.67 \\
\hline Cephalopholis panamensis ${ }^{1}$ & 1.27 & $1.75 \pm 0.09$ & 72.82 & 0.17 & $0.15 \pm 0.02$ & 13.30 \\
\hline Haemulon sexfasciatum ${ }^{1}$ & 0.84 & $1.18 \pm 0.50$ & 10.60 & 0.12 & $0.10 \pm 0.03$ & 5.96 \\
\hline Halichoeres chierchiae 5 & 1.12 & $1.66 \pm 0.11$ & 67.54 & 0.06 & $0.06 \pm 0.02$ & 4.21 \\
\hline Halichoeres nicholsi ${ }^{5}$ & 1.31 & $1.97 \pm 0.10$ & 73.03 & 0.05 & $0.05 \pm 0.01$ & 3.89 \\
\hline Cirrhitichthys oxycephalus ${ }^{5}$ & 0.84 & $1.23 \pm 0.09$ & 49.01 & 0.02 & $0.02 \pm 0.01$ & 1.30 \\
\hline Haemulon maculicauda ${ }^{5}$ & 1.53 & $2.32 \pm 0.37$ & 17.55 & 0.01 & $0.01 \pm 0.01$ & 0.59 \\
\hline
\end{tabular}

\section{Fish assemblage variation over spring/neap tides (Question 2)}

Analysis of the effect of tidal amplitude was based on 3 (high tide, ebb tide, flood tide) of the 4 tidal stages, since data could not be collected at low tide in the intertidal zone. In subtidal zones, the PERMANOVA analysis showed significant differences in fish assemblages among sites, but not between spring and neap tides (Table 2). This was further confirmed by the CAP analysis, which showed little differences between spring and neap tide multivariate data (Table 3). The overall leave-one-out allocation success in the discriminant analysis was $59.2 \%$, which is very near a value suggesting a random distribution of samples $(50 \%$ allocation success) when considering only 2 groups (spring and neap). Hence, fish assemblages of subtidal transects did not differ consistently between spring and neap tides.

In the intertidal zone, the effects of Site and Amplitude were both statistically significant, as was the interaction between them (Table 2). Variation in multivariate dispersion was not the cause (PERMDISP, $\mathrm{p}>0.15$ at all 4 sites), so sites were subjected to PCO ordination separately, which showed that there were differences between spring and neap tides at Cocalito 1 , some differences at Cocalito 2, but no difference at the remaining 2 sites (Fig. 2), which explains the significant interaction term. The Amplitude difference at both Cocalito sites was primarily due to higher densities of Mugil curema found in intertidal habitats during neap tides (see biplots overlaying, Fig. 2). These differences were reflected in the CAP 
Table 2. Results of 2-way mixed model PERMANOVAs testing the effects of tidal amplitude (spring vs. neap) on Utría subtidal and intertidal reef fish assemblages at 4 sites (Site is treated as a random effect and Amplitude as a fixed effect). Subtidal samples were pooled omitting low tide observations. Data from surveys carried out from November 2007 to March 2008

\begin{tabular}{|lccccc|}
\hline $\begin{array}{l}\text { Subtidal } \\
\text { Source }\end{array}$ & $\mathrm{df}$ & $\mathrm{SS}$ & $\mathrm{MS}$ & $F$ & $\mathrm{p}$ \\
\hline Site & 3 & 96445 & 32148 & 29.26 & 0.0002 \\
Amplitude & 1 & 1694 & 1694 & 1.24 & 0.2676 \\
Site $\times$ Amplitude & 3 & 4134 & 1378 & 1.25 & 0.1214 \\
Residual & 279 & 306510 & 1098 & & \\
Total & 286 & 410470 & & & \\
Intertidal & & & & & \\
Source & $\mathrm{df}$ & $\mathrm{SS}$ & $\mathrm{MS}$ & $F$ & $\mathrm{p}$ \\
\hline Site & 3 & 99150 & 33050 & 30.18 & 0.0002 \\
Amplitude & 1 & 4346 & 4346 & 1.76 & 0.0089 \\
Site $\times$ Amplitude & 3 & 7568 & 2523 & 2.30 & 0.0002 \\
Residual & 241 & 263920 & 1095 & & \\
Total & 248 & 377230 & & & \\
\hline
\end{tabular}

analysis, which returned a somewhat higher allocation success to spring tides (Table 3). Hence, differences between spring and neap tide intertidal assemblages were only observed at 2 sites on which the presence of a single species accounted for most of the variation at neap tides.

\section{Subtidal fish assemblage variation with tidal stage (Question 3)}

A 2-way mixed-model PERMANOVA using subtidal data ( 4 sites $\times 4$ tidal stages; tidal amplitude was omitted on the basis of the result above) showed significant differences in fish assemblages at different tidal stages and different sites (with no interaction between these 2 main effects, Table 4). This was indicative of consistent differences in fish assemblages between tidal stages regardless of site. Pairwise comparisons indicated that the main differences were observed between high-flood and lowebb combinations of tidal stages. These results were confirmed by the individual CAPs for each site (Fig. 3). At 2 sites (Punta Diego and Playa Blanca), low water and ebb tide samples were distributed to the left, whereas high water and flood tide samples aligned to the right of the CAP axis 1 (CAP1, Fig. 3). At Cocalito 2, low water samples were also distributed to the left, but ebb tides samples tended to be more separated by CAP2. At Cocalito 1, there was little separation between groups. The principal species for which significant correlations with 1 of the canonical discriminant axes were found were Thalassoma lu- casanum, Kyphosus elegans and Halichoeres chierchiae (associated with low water and ebb tides), and Cephalopholis panamensis, Bodianus diplotaenia and Sufflamen verres (associated with high water and flood tides; Table 5, Fig. 4).

\section{Intertidal versus subtidal fish assemblage variation at high tide (Question 4)}

A 2-way PERMANOVA testing site and zone returned significant main effects as well as a significant interaction between them (Table 6). The significant Site $\times$ Zone interaction is explained by the CAP ordination: although sites are discriminated along CAP2, and CAP1 generally separates subtidal samples from intertidal samples at all sites, the degree of intertidal/subtidal separation at Punta Diego and Cocalito 2 is much greater than seen at Playa Blanca and Cocalito 1 (Fig. 5a). Overall leave-one-out allocation success for the CAP analysis was $89.6 \%$, with few misallocations occurring between sites, and none between tidal zones. This indicates that while both site and tidal zone were strong and predictable determinants of fish high tide assemblage structure, between-zone differences within sites were stronger than those between sites.

Differences between both Cocalito sites and Punta Diego and Playa Blanca were attributed to differences in densities of Ophioblennius steindachneri and Microspathodon dorsalis. Most of the dissimilarities between Punta Diego and the rest of the subtidal sites were accounted for by Canthigaster punctatissima (Fig. 5b).

\section{Intertidal key fish species and effects of tidal stage on their counts (Question 5)}

There were strong species correlations with the first canonical axis, corresponding to the separation of subtidal and intertidal assemblages (Fig. 5b). The
Table 3. Results of canonical analysis of principal coordinates (CAP) testing the effect of tidal amplitude (spring vs. neap) on Utría subtidal reef fish assemblages. \%Var: percentage of the total variation explained by the first $m$ principal coordinate axes; allocation success: percentage of points correctly allocated into each group; $\delta^{2}$ : square canonical correlation

\begin{tabular}{|lcccccccc|}
\hline Data & $m$ & \%Var & \multicolumn{2}{c}{ Allocation success (\%) } & Total & \multirow{2}{*}{$\delta^{2}$} & $\mathrm{p}$ \\
& & & Neap & Spring & & & \\
\hline Subtidal & 20 & 95.34 & 62.09 & 56.18 & 59.17 & 0.1252 & 0.0004 \\
Intertidal & 15 & 97.38 & 56.74 & 67.59 & 61.45 & 0.173 & 0.0002 \\
\hline
\end{tabular}



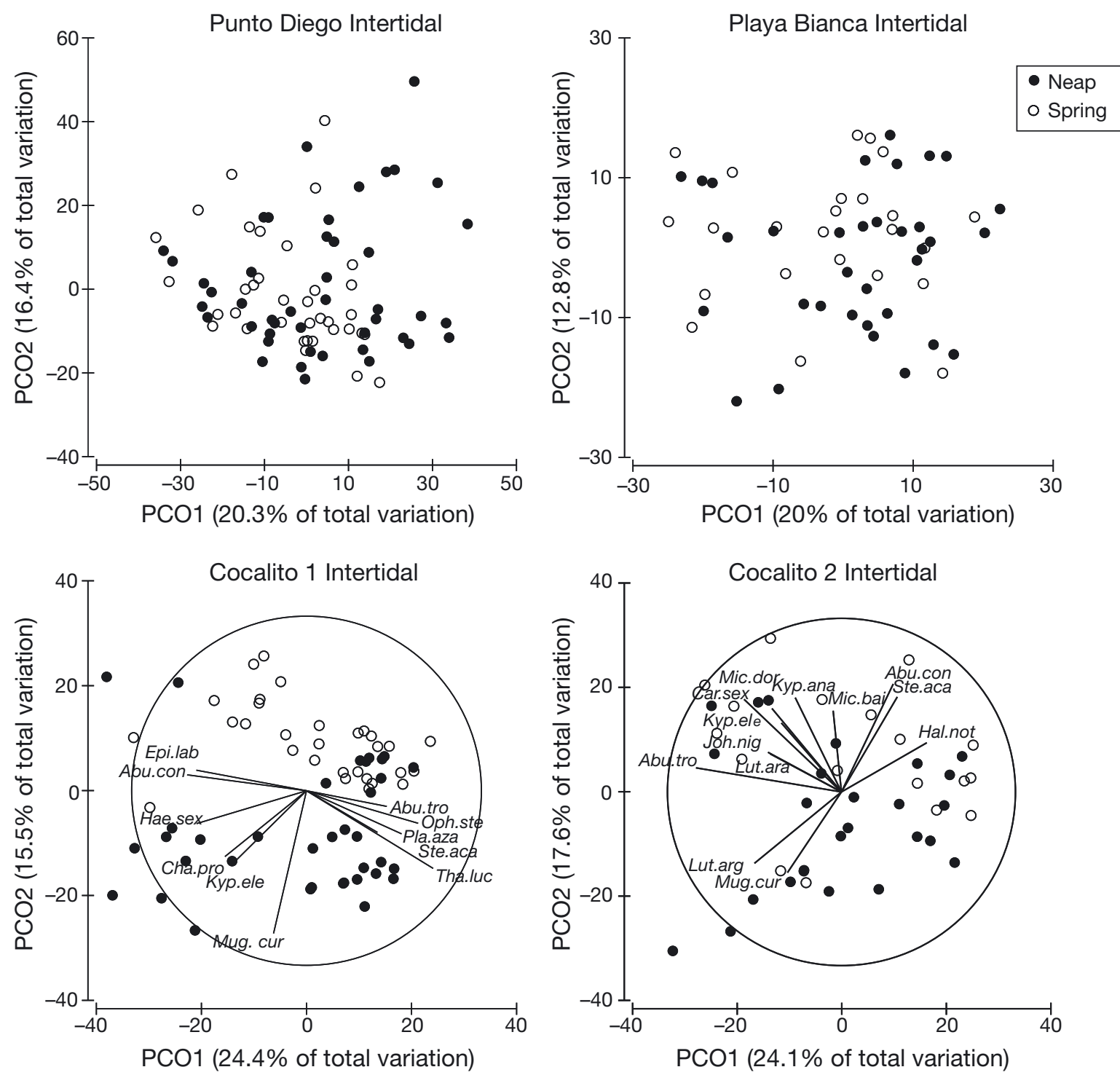

Fig. 2. Principal coordinate analysis (PCO) ordinations of intertidal fish assemblages at 4 sites during high tide showing variation between neap and spring tides. See Table 1 for full species names (indicated here with the first 3 letters of generic and species name, respectively)

4 species that were strongly correlated with intertidal assemblages at high tide (i.e. positively correlated with CAP1 of Fig. 5a) also tended to be those that were associated with low water subtidal assemblages in earlier analyses (Table 5). This indicates that these species (Kyphosus elegans, Abudefduf concolor, Halichoeres notospilus and Microspathodon bairdii) make regular excursions to intertidal zones on the rising tide, returning to subtidal habitats as the tide ebbs.

Log-linear model estimates of the difference between low tide and high tide counts of these 4 species (Fig. 6) showed that subtidal counts made during high tide may underestimate actual abundance by anything from $140 \%$ (for Halichoeres notospilus) to $1260 \%$ (for Kyphosus elegans; Table 7).

Table 4. Results of 2-way mixed model PERMANOVA testing the effects of tidal stage (low water, flood tide, high water, ebb tide) on Utría subtidal reef fish assemblages at 4 sites

\begin{tabular}{|lccccc|}
\hline Source & df & SS & MS & $F$ & $p$ \\
\hline Site & 3 & 111670 & 37224 & 33.095 & 0.0002 \\
Tidal stage & 3 & 8019 & 2673 & 2.1646 & 0.0008 \\
Site $\times$ Tidal stage & 9 & 11168 & 1240.9 & 1.1033 & 0.2166 \\
Residual & 344 & 386920 & 1124.8 & & \\
Total & 359 & 524070 & & & \\
\hline
\end{tabular}




\section{DISCUSSION}

This study shows that a high proportion of the fish species inhabiting shallow subtidal areas $(>70 \%)$ may use the adjacent rocky intertidal areas during inundation periods, but that certain species-especially highly mobile schooling species-may desert the subtidal reefs almost entirely at high tide and forage in the intertidal zone. This is similar to findings from mangrove creek systems of Brazil, where most of the species inhabiting adjacent subtidal habitats at low tide were later found in the intertidal creeks (Krumme et al. 2004). This strategy, classified by Gibson (2003) as intertidal migration, is found in both temperate and tropical intertidal areas (e.g. Kneib 1987, Burrows et al. 1994, Rangeley \& Kramer 1995, Faria \& Almada 2006). However it remains largely unknown how consistent these migrations are at different levels: among species within an assemblage, among individuals within populations and in individuals themselves (Pittman \& McAlpine 2003). The scarce evidence suggests the existence of at least 3 patterns at the population level: (1) the movement of the whole population into a higher tidal level, (2) an up-shore spreading of the population
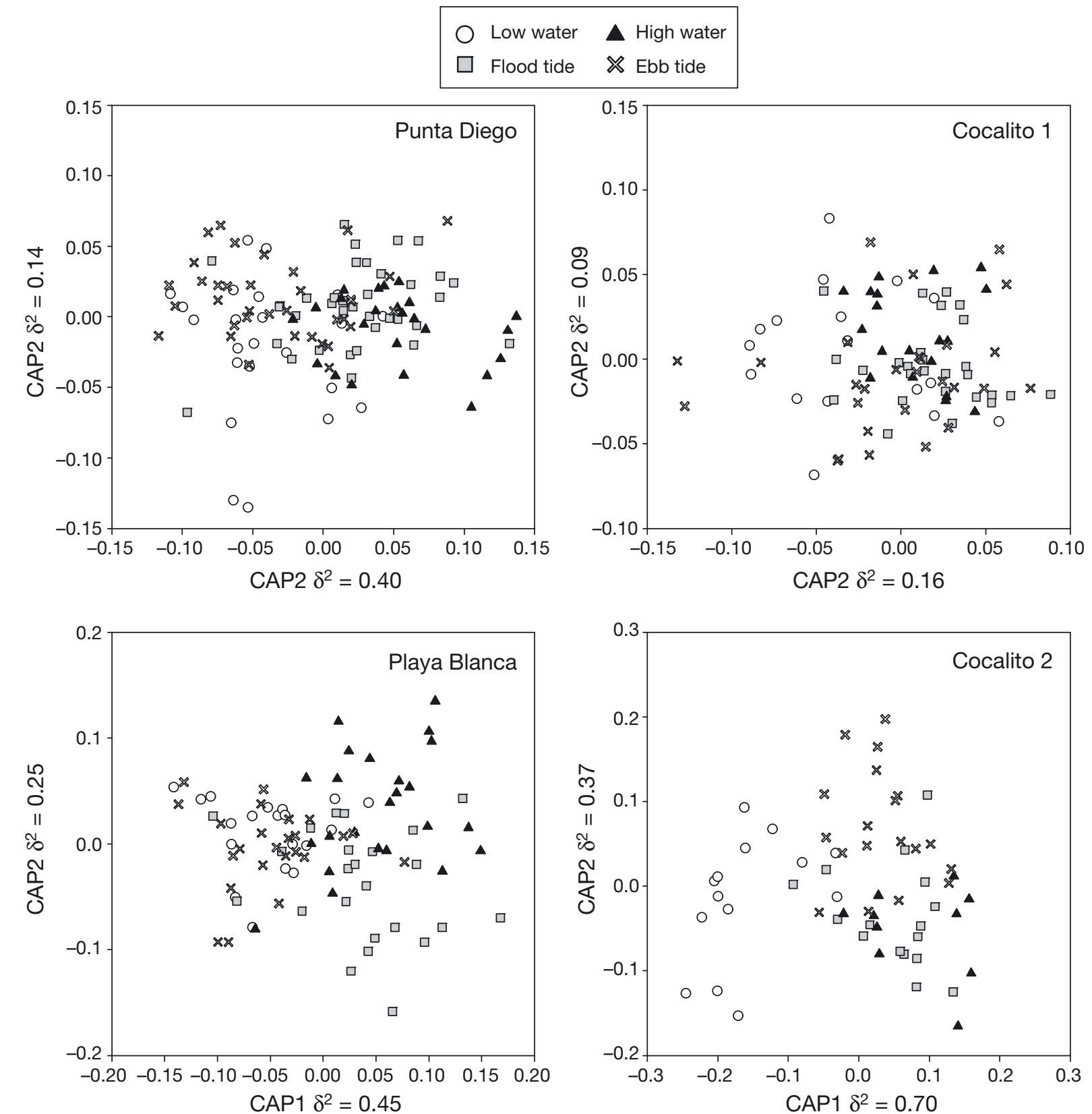

Fig. 3. Canonical analysis of principal coordinates (CAP) of Utría reef fish transect counts taken at different tidal stages in the subtidal zone at 4 sites. $\delta^{2}$ : square canonical correlation 
Table 5. Fish species with significant correlations with canonical analysis of principal coordinates (CAP) axis 1 or 2 (CAP1 or CAP2) in Fig. 3. Species with negative correlations with CAP1 are associated with samples on the left of the CAP plot and species with positive correlations with samples to the right

\begin{tabular}{|c|c|c|c|c|c|c|c|c|}
\hline \multirow{2}{*}{ Species } & \multicolumn{2}{|c|}{ Punta Diego } & \multicolumn{2}{|c|}{ Playa Blanca } & \multicolumn{2}{|c|}{ Cocalito 1} & \multicolumn{2}{|c|}{ Cocalito 2} \\
\hline & CAP1 & CAP2 & CAP1 & CAP2 & CAP1 & CAP2 & CAP1 & CAP2 \\
\hline Thalassoma lucasanum & -0.4742 & 0.3012 & -0.3084 & & -0.375 & & -0.2034 & 0.5871 \\
\hline Abudefduf troschelii & -0.4153 & & & & & & & \\
\hline Kyphosus elegans & -0.3749 & 0.3043 & 0.2081 & -0.3497 & -0.5356 & -0.2326 & -0.23 & 0.4934 \\
\hline Halichoeres chierchiae & -0.3369 & 0.43 & -0.3065 & & & & 0.3343 & 0.2978 \\
\hline Halichoeres notospilus & -0.2625 & -0.2003 & & & & & & \\
\hline Haemulon maculicauda & -0.2252 & 0.2697 & 0.2948 & & & & & \\
\hline Bodianus diplotaenia & -0.2059 & & 0.2454 & & 0.3115 & -0.259 & & \\
\hline Cephalopholis panamensis & 0.2181 & & & & 0.2163 & -0.306 & 0.4815 & \\
\hline Halichoeres dispilus & 0.2436 & 0.2437 & & & & & & \\
\hline Mulloidichthys dentatus & 0.3056 & 0.3623 & & & & & & \\
\hline Ophioblennius steindachneri & & & -0.4936 & -0.306 & 0.2656 & & & \\
\hline Microspathodon bairdii & & & -0.4489 & & & & -0.6913 & -0.2111 \\
\hline Axoclinus lucillae & & & -0.385 & & & & 0.2091 & \\
\hline Chaetodon humeralis & & & -0.3342 & & & & & \\
\hline Plagiotremus azaleus & & & -0.2907 & & & & & \\
\hline Sargocentron suborbitalis & & & -0.274 & & & & & \\
\hline Mugil curema & & & -0.2437 & -0.2266 & & & & \\
\hline Acanthemblemaria exilispinus & & & -0.2197 & & & & & \\
\hline Abudefduf concolor & & & -0.2061 & & -0.3236 & 0.3325 & -0.6129 & \\
\hline Sufflamen verres & & & 0.276 & & 0.2289 & -0.2648 & 0.3298 & \\
\hline Scarus rubroviolaceus & & & 0.2763 & & & & & \\
\hline Canthigaster punctatissima & & & & & -0.3072 & & 0.2066 & \\
\hline
\end{tabular}

due to individuals' differential movement and (3) an ontogenetic separation of the population into migrant and non-migrant individuals each tide (Gibson 2003), e.g. where only juvenile fish from a particular species migrate into the intertidal zone and sub-adult and adult fish stay in subtidal areas.

We found 3 times more fish species entering rocky intertidal areas compared to similar studies carried out within the tropical eastern Pacific region (Lubchenco et al. 1984, Vinueza et al. 2006), most probably due to a greater sampling intensity. However, similarities between the fish assemblage compositions of these studies were evident. In Taboguilla Island (Panama), Lubchenco et al. (1984) found 22 species in rocky intertidal shores that were common to the present study, except for 3 species (Balistes polylepis, Prionurus punctatus, Nicholsina denticulata). For the Galápagos Islands, Vinueza et al. (2006) reported 19 species at high tide in intertidal rocky shores with a predominance of species from Pomacentridae and Labridae. Fourteen of these species are shared with Utría. Among the 5 species that are not shared, Stegastes arcifrons, which is very abundant in the Galapagos, is likely replaced by its sister species, $S$. acapulcoensis, in Utría. This suggests that tidal migrations in rocky shores of the region are consistent in space and constitute an important and overlooked part of the homerange movements of a relatively high number of reef fish species.
Six different migratory categories for reef fishes in Utría were observed: (1) opportunistic benthic reef fish species of a broad size class spectrum who entered intertidal areas, (2) ubiquitous schooling species that moved from outside reefs into intertidal areas, belonging to the families Kyphosidae, Carangidae and Mugilidae, (3) small size classes of reef fish species that entered intertidal areas (i.e. Scaridae), (4) reef fish that moved up-shore from deeper reefs with the tides, but did not enter intertidal areas (i.e. Paranthias colonus), (5) reef fish that moved in the water column, not necessarily to intertidal areas, with tidal stage changes, and (6) intertidal resident species (i.e. Malacoctenus sp.). Similar divisions were drawn by Vivien (1973) for reef fishes off Madagascar where tidal responses were very variable among species. The assemblage was split into a 'permanent' portion that appeared unaltered by the tidal change, and a 'temporary' portion that moves to feed in shallow reef areas with the tides.

The spring/neap tide cycle has been shown to influence coastal fish assemblages at different levels (Krumme et al. 2004). In mangroves of northern Brazil, clear relationships between spring tides and an increase in species richness, abundance and catch weight of fishes entering intertidal creeks were found. The results obtained in Utría - where the tidal regime is similar to northern Brazil-indicate that reef fish assemblages in intertidal and subtidal areas at day- 

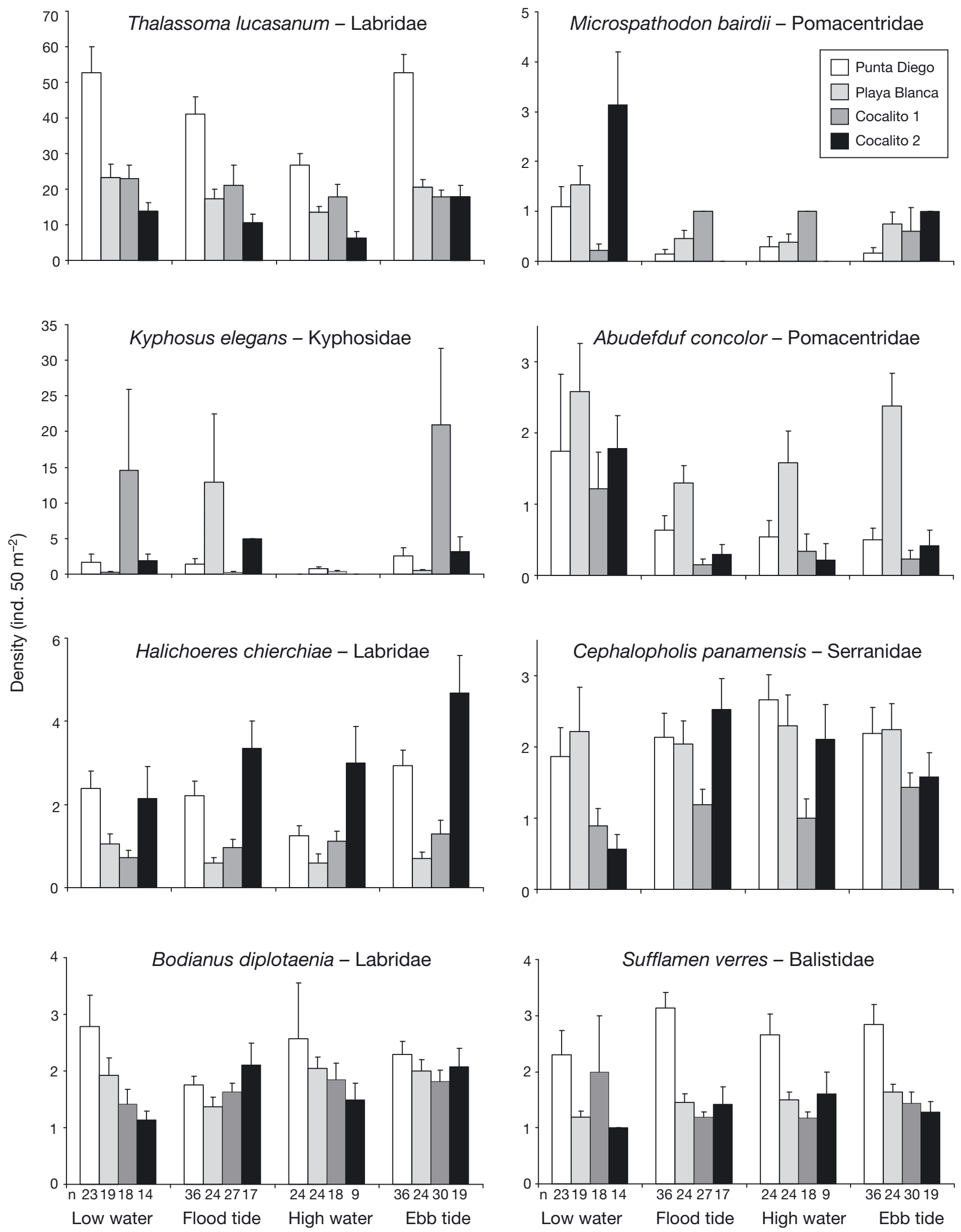

Fig. 4. Mean density $(+\mathrm{SE})$ of the principal fish species responsible for differences between tidal stages at the 4 sites 
Table 6. Comparison of subtidal and intertidal fish assemblages at high water at 4 sites using mixed effects PERMANOVA. Type III (partial) sums of squares was used, and $\mathrm{p}$ values were generated using 5000 permutations of residuals under the reduced model

\begin{tabular}{|lccccc|}
\hline Source & df & SS & MS & Pseudo- $F$ & $p$ \\
\hline Site & 3 & 37046 & 12349 & 10.47 & 0.0002 \\
Zone & 1 & 64583 & 64583 & 6.89 & 0.0006 \\
Site $\times$ Zone & 3 & 31020 & 10340 & 8.77 & 0.0002 \\
Residual & 136 & 160380 & 1179 & & \\
Total & 143 & 299780 & & & \\
\hline
\end{tabular}

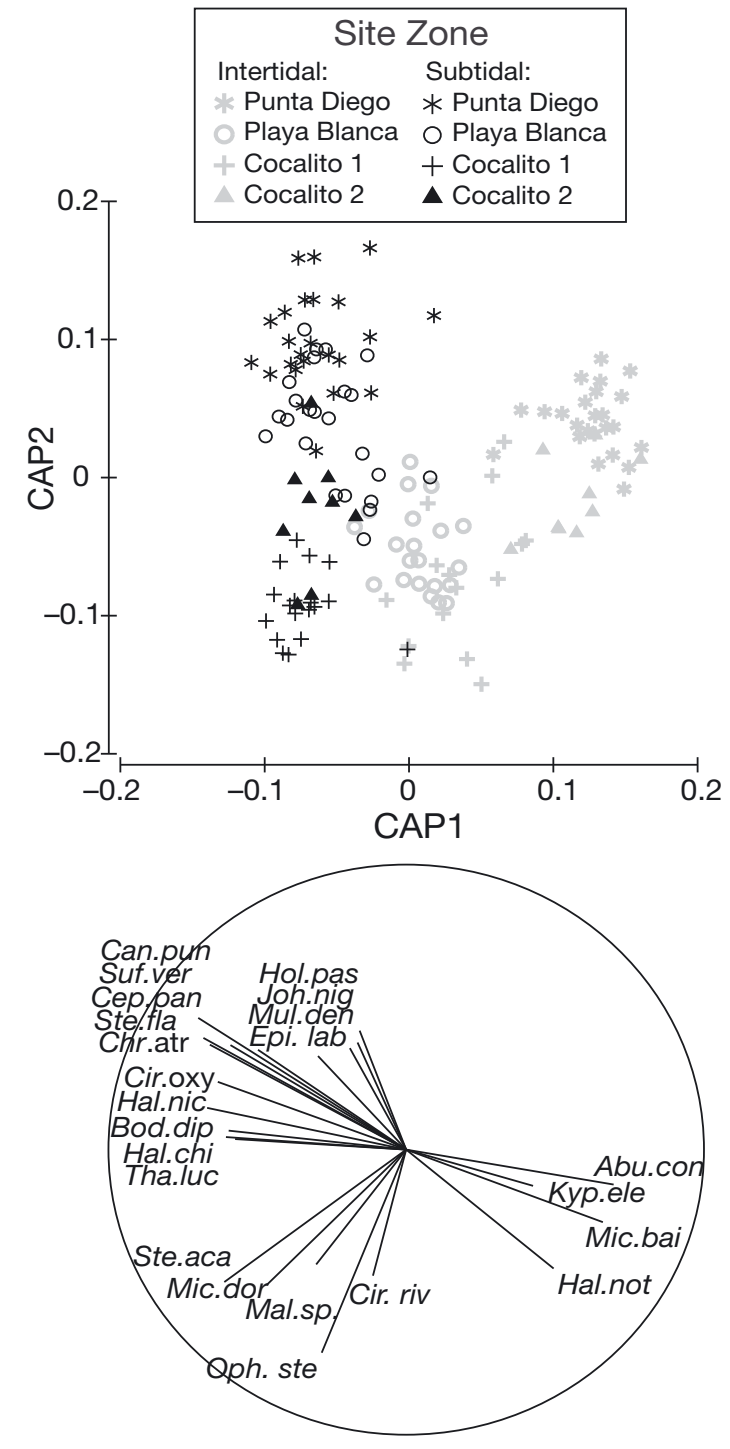

Fig. 5. Canonical analysis of principal coordinates (CAP) of Utría reef fish transect counts taken at intertidal and subtidal areas at high tide. (a) Constrained ordination: proportion of variance explained $=0.95, \delta_{\text {CAP1 }}^{2}=0.91, \delta_{\text {CAP2 }}^{2}=0.78$. (b) Biplot showing individual species correlations with the 2 CAP axes where $|r|>0.4$. See Table 1 for full species names (indicated here with the first 3 letters of generic and species names, respectively) light were little affected by the spring/neap tide alternation. In Utría, a larger intertidal area available during spring tides did not attract more fishes. This may be reasonable in rocky shores of the tropical eastern Pacific, where prey or food resources for fishes are usually more abundant and concentrated in low intertidal areas (Lubchenco et al. 1984). Therefore, foraging in the upper intertidal zones, only available at spring tides and during a limited time, may not represent an advantage compared to low intertidal zones (Rilov \& Schiel 2006). This highlights a major habitat-specific difference in the intertidal habitat use by fishes. For example, temporal patterns in intertidal mangrove use by fishes were explained by the greater inundated area and food accessibility in mangroves at spring tides in Brazil (Krumme et al. 2004, Krumme \& Liang 2004). If it is considered that a large biomass of organisms (especially crabs) is concentrated in upper intertidal levels of mangroves (Koch 1999), spring tides may provide fishes a very rich food source when accessing high intertidal areas. Consequently, we suggest that the vertical distribution of food resources in different intertidal habitats may influence the magnitude of spring-neap tide fish migrations to these habitats. We propose that the overall ecological significance of fish intertidal migrations in different system habitats (but subject to similar tidal regimes) may be dictated by the specific characteristics of each intertidal habitat. In rocky shores or sandy beaches, greater colonisation at spring tides may be a lower pay-off strategy for fishes due to relatively small inundated areas and intertidal

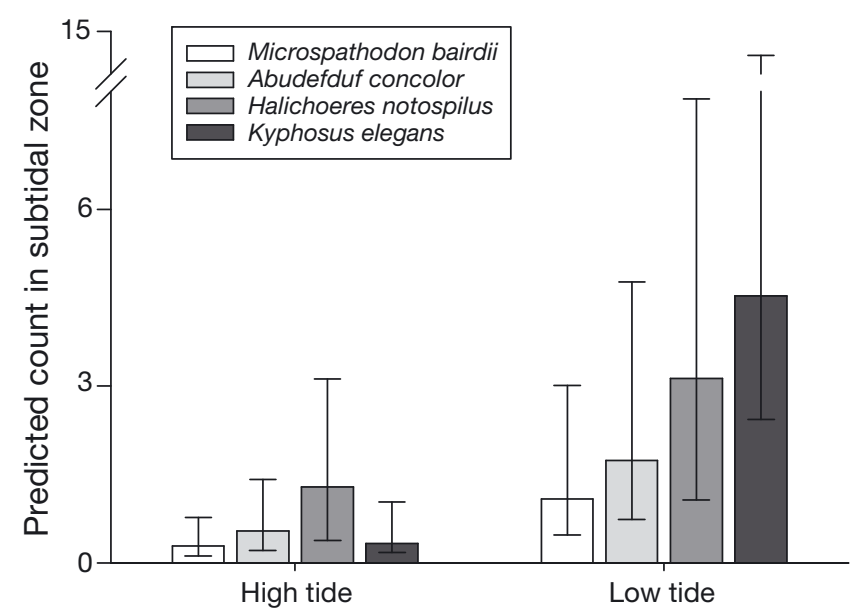

Fig. 6. Predicted subtidal counts $( \pm \mathrm{SE})$ of 4 key fish species during high tide and low tide. Note that error bars are of unequal length around the point estimate because the SE are calculated on the log scale, and hence are multiplicative on the arithmetic scale 
Table 7. Log-linear model estimates of differences in density between subtidal counts of key fish species at high tide and low tide expressed as ratios (low tide:high tide) with their $95 \%$ confidence limits (CL) and likelihood ratio statistics

\begin{tabular}{|lcccrr|}
\hline Species & $\begin{array}{c}\text { Ratio (low tide: } \\
\text { high tide) }\end{array}$ & $\begin{array}{c}\text { Lower 95\% } \\
\text { CL for ratio }\end{array}$ & $\begin{array}{c}\text { Upper 95\% } \\
\text { CL for ratio }\end{array}$ & $\chi^{2}$ & p \\
\hline Microspathodon bairdii & 3.7 & 1.2 & 11.5 & 5.3 & 0.022 \\
Abudefduf concolor & 3.2 & 1.1 & 9.5 & 4.4 & 0.036 \\
Halichoeres notospilus & 2.4 & 1.1 & 5.5 & 4.5 & 0.033 \\
Kyphosus elegans & 13.6 & 3.0 & 61.5 & 11.5 & $<0.001$ \\
\hline
\end{tabular}

tance of fish predation in regulating macroalgae and invertebrate intertidal communities.

Although differences between the 4 sampling sites in Utría were detected, they were less strong than the subtidal/intertidal differences consistently observed among the 4 sampling sites. This indicates that the intertidal fish assemblage was comprised of a

prey resources concentrated in the lower eulittoral. In contrast, fishes on coasts with intertidal mangrove or saltmarsh system habitats may greatly benefit from stronger colonisation at spring tides due to relatively large inundated areas with dendritic creek systems and intertidal prey resources concentrated in the higher eulittoral (e.g. Brenner \& Krumme 2007, Krumme et al. 2008).

The results obtained for reef fishes in Utría indicate that these migrations are species-specific. This has also been found in mangrove fishes of Brazil (Brenner \& Krumme 2007, Krumme et al. 2008). The small changes observed in the subtidal reef fish assemblage over the tidal cycle indicate that intertidal migrations were restricted to just a few species of the entire reef fish assemblage; and even more, to only one part of a population within these specific species. Similar results were obtained in mangrove systems of Florida by Ellis $\&$ Bell (2008), where only 1 group of species (Eucinostomus spp.) showed clear tide-related movements. Using acoustic telemetry at Puget Sound (USA), Tolimieri et al. (2009) found different patterns in the movement behaviour and home range size of 3 fish species. The movement behaviour, however, was related to the diel and tidal cycles in the 3 species, with some of them moving at daylight on the flood tide, while others moved at night on the flood tide. Movements of entire populations from subtidal to intertidal areas, as found by Rangeley \& Kramer (1995) in pollock (Pollachius virens, Gadidae) populations, were rare in Utría, although groups of the bumphead damselfish Microspathodon bairdii were found to regularly commute between distinct subtidal and intertidal sites.

Despite resource accessibility being restricted to immersion periods, the few common fish species entering intertidal areas may exert strong top-down control on rocky shore communities of the area as suggested by Lubchenco et al. (1984). In Utría, species from herbivorous (i.e. Kyphosidae, Mugilidae, Scaridae) and carnivorous guilds (i.e. Labridae, Lutjanidae) were among the most common in intertidal areas and were observed feeding intensively there (G. A. Castellanos Galindo pers. obs). Further manipulative studies on these rocky shores are needed to determine the impor- defined subset of subtidal species. The observed site differences in both subtidal and intertidal fish assemblages in Utría may be a consequence of the degree of wave exposure of the sites, as well as a function of small-scale differences in habitat (Santin \& Willis 2007). Wave exposure has been suggested to be a major factor shaping the structure of fish communities (Fulton et al. 2005), and although it was not measured in this study, is likely to affect the fish community structure of rocky and coral reef areas of the region.

The variability in reef fish responses over tidal stages raises the question of whether tidal stages should be considered in reef fish monitoring in macrotidal areas. Surprisingly few studies have acknowledged the potential bias that fish censuses carried out at different times of the day or tidal stages may have (but see Kingsford \& MacDiarmid 1988, Thompson \& Mapstone 2002, Willis et al. 2006, McClanahan et al. 2007). Small differences in overall fish assemblage structure, as determined by multivariate analyses, can mask large and predictable changes in the densities of individual species, especially where the dataset consists of many species and there are compositional differences among sites (Willis et al. 2006). In New Zealand and Italy, Willis et al. (2006) found no significant differences in the reef fish assemblage structure at 3 different times during daylight hours. However, they did not sample over a complete tidal cycle. Nevertheless, they pointed out that if common species exhibit strong differences in activity patterns during the day due to tidal redistribution, for example, comparing counts taken at different tidal stages may result in significant bias. In our study, univariate analyses showed clearly that at Utría, counts of some common species that habitually use intertidal habitats may vary in relative density by more than $100 \%$ (much more for schooling species) between high and low tide. Thus, subtidal fish counts conducted at high tide may significantly underestimate the density of important species at local scales and introduce bias at the site level that increases the variance of counts across larger scales. Importantly, studies of the trophic structure of coastal systems could underestimate the extent of herbivory, for example, if schooling fishes forage extensively in intertidal zones. 
Acknowledgements. Support for this research was given by the Rufford Small Grant foundation (UK) and DAAD (Germany) through a scholarship given to G.A.C.G. Colombian National Park authorities granted access to the park through permit No. DTNO-U-31 10/'7 and allowed sampling activities. A. Giraldo provided essential support during the field stage of the project through his research group at Universidad del Valle. Logistic and technical assistance during visual census activities was provided by A. Villa. Comments by S. Navarrete, R.N. Gibson and C. Faria at initial stages of this project are greatly appreciated. Confirmation of fish identifications by D.R. Robertson during the field stage was extremely helpful. The collaboration of local fishermen (H. Villalba and J. E. Mosquera) is gratefully appreciated. Three anonymous reviewers provided helpful comments that improved the quality of the manuscript.

\section{LITERATURE CITED}

Anderson MJ (2001) A new method for non-parametric multivariate analysis of variance. Austral Ecol 26:32-46

Anderson MJ (2006) Distance-based tests for homogeneity of multivariate dispersions. Biometrics 62:245-253

Anderson MJ, Willis TJ (2003) Canonical analysis of principal coordinates: a useful method of constrained ordination for ecology. Ecology 84:511-525

Anderson MJ, Gorley RN, Clarke KR (2008) PERMANOVA+ for PRIMER: guide to software and statistical methods. PRIMER-E, Plymouth

Ansell AD, Gibson RN (1990) Patterns of feeding and movement of juvenile flatfishes on an open sandy beach. In: Barnes M, Gibson RN (eds) Trophic relationships in the marine environment. Proc 24th Eur Mar Biol Symp. Eur Mar Biol Symp 24:191-207

Brenner M, Krumme U (2007) Tidal migration and patterns in feeding of the four-eyed fish Anableps anableps L. in a north Brazilian mangrove. J Fish Biol 70:406-427

Burrows MT, Gibson RN, Robb L, Comely CA (1994) Temporal movement patterns of juvenile flatfishes and their predators: underwater television observations. J Exp Mar Biol Ecol 177:251-268

Coates AG, Obando JA (1996) The geologic evolution of the Central American Isthmus. In: Jackson JBC, Budd AF, Coates AG (eds) Evolution and environments in tropical America. University of Chicago Press, Chicago, IL, p 21-56

Dingle H (1996) Migration: the biology of life on the move. Oxford University Press, New York, NY

> Dorenbosch M, Verweij MC, Nagelkerken I, Jiddawi N, van der Velde G (2004) Homing and daytime tidal movements of juvenile snappers (Lutjanidae) between shallow-water nursery habitats in Zanzibar, western Indian Ocean. Environ Biol Fishes 70:203-209

Ellis WL, Bell SS (2008) Tidal influence on a fringing mangrove intertidal fish community as observed by in situ video recording: implications for studies of tidally migrating nekton. Mar Ecol Prog Ser 370:207-219

Faria C, Almada VC (2006) Patterns of spatial distribution and behaviour of fish on a rocky intertidal platform at high tide. Mar Ecol Prog Ser 316:155-164

Fulton CJ, Bellwood DR, Wainwright PC (2005) Wave energy and swimming performance shape coral reef fish assemblages. Proc Biol Sci 272:827-832

Garzón-Ferreira J, Reyes-Nivia MC, Rodríguez-Ramírez A (2002) Manual de métodos del Simac: Sistema Nacional de Monitoreo de Arrecifes Coralinos en Colombia. Instituto de Investigaciones Marinas y Costeras José Benito Vives de Andréis, Santa Marta
Gibson RN (1992) Tidally synchronized bahaviour in marine fishes. In: Ali MA (ed) Rhythms in fishes. Plenum Press, New York, NY, p 55-63

Gibson RN (1999) Movement and homing in intertidal fishes. In: Horn MH, Martin KLM, Chotkowski MA (eds) Intertidal fishes: life in two worlds. Academic Press, San Diego, CA, p 97-125

Gibson RN (2003) Go with the flow: tidal migration in marine animals. Hydrobiologia 503:153-161

Glynn PW, Ault JS (2000) A biogeographic analysis and review of the far eastern Pacific coral reef region. Coral Reefs 19:1-23

> Grigg RW, Hey R (1992) Paleoceanography of the tropical eastern Pacific Ocean. Science 255:172-178

IDEAM (Instituto de Hidrología, Meterorología y Estudios Ambientales) (2006) Pronóstico pleamares y bajamares costa Pacífica Colombiana 2007. IDEAM, Bogotá

IDEAM (2007) Pronóstico pleamares y bajamares costa Pacífica Colombiana 2008. IDEAM, Bogotá

> Kingsford MJ, MacDiarmid AB (1988) Interactions between planktivorous reef fish and zooplankton in temperate waters. Mar Ecol Prog Ser 48:103-117

- Kneib RT (1987) Predation risk and use of intertidal habitats by young fishes and shrimp. Ecology 68:379-386

Kneib RT (1997) The role of tidal marshes in the ecology of estuarine nekton. Oceanogr Mar Biol Annu Rev 35: $163-220$

Koch V (1999) Epibenthic production and energy flow in the Caeté mangrove estuary, North Brazil. ZMT Contributions 6, Center for Tropical Marine Ecology (ZMT), Bremen

Krumme U, Liang TH (2004) Tidal induced changes in a copepod-dominated zooplankton community in a macrotidal mangrove channel in northern Brazil. Zool Stud 43: 405-415

Krumme U, Saint-Paul U, Rosenthal H (2004) Tidal and diel changes in the structure of a nekton assemblage in small intertidal mangrove creeks in northern Brazil. Aquat Living Resour 17:215-229

> Krumme U, Brenner M, Saint-Paul U (2008) Spring-neap cycle as a major driver of temporal variations in feeding of intertidal fishes: evidence from the sea catfish Sciades herzbergii (Ariidae) of equatorial west Atlantic mangrove creeks. J Exp Mar Biol Ecol 367:91-99

Laffaille P, Feunteun E, Lefeuvre JC (2000) Composition of fish communities in a European macrotidal salt marsh (the Mont Saint-Michel Bay, France). Estuar Coast Shelf Sci 51: $429-438$

Lubchenco L, Menge BA, Garrity SD, Lubchenco PJ and others (1984) Structure, persistence and role of consumers in a tropical rocky intertidal community (Taboguilla Island, Bay of Panama). J Exp Mar Biol Ecol 78:23-73

> McClanahan TR, Graham NAJ, Maina J, Chabanet P, Bruggeman JH, Polunin NVC (2007) Influence of instantaneous variation on estimates of coral reef fish populations and communities. Mar Ecol Prog Ser 340:221-234

Norton SF, Cook AE (1999) Predation by fishes in the intertidal. In: Horn MH, Martin KLM, Chotkowski MA (eds) Intertidal fishes: life in two worlds. Academic Press, San Diego, CA, p 223-263

Palmer JD (2000) The clocks controlling the tide-associated rhythms of intertidal animals. Bioessays 22:32-37

> Pittman SJ, McAlpine CA (2003) Movements of marine fish and decapod crustaceans: process, theory and application. Adv Mar Biol 44:205-294

Rangeley RW, Kramer DL (1995) Tidal effects on habitat selection and aggregation by juvenile pollock Pollachius virens in the rocky intertidal zone. Mar Ecol Prog Ser 126:19-29 
Rilov G, Schiel DR (2006) Trophic linkages across seascapes: subtidal predators limit effective mussel recruitment in rocky intertidal communities. Mar Ecol Prog Ser 327:83-93

Robertson AI (1980) The structure and organization of an eelgrass fish fauna. Oecologia 47:76-82

Robertson DR, Cramer KL (2009) Shore fishes and biogeographic subdivisions of the tropical eastern Pacific. Mar Ecol Prog Ser 380:1-17

Robertson DR, Grove JS, McCosker JE (2004) Tropical transpacific shore fishes. Pac Sci 58:507-565

Santin S, Willis TJ (2007) Direct versus indirect effects of wave exposure as a structuring force on temperate cryptobenthic fish assemblages. Mar Biol 151:1683-1694

Sheaves M (2005) Nature and consequences of biological connectivity in mangrove systems. Mar Ecol Prog Ser 302: 293-305

Thompson AA, Mapstone BD (2002) Intra- versus interannual variation in counts of reef fishes and interpretations of long-term monitoring studies. Mar Ecol Prog Ser

Editorial responsibility: Tim McClanahan, Mombasa, Kenya
232: $247-257$

Tolimieri N, Andrews K, Williams G, Katz S, Levin PS (2009) Home range size and patterns of space use by lingcod, copper rockfish and quillback rockfish in relation to diel and tidal cycles. Mar Ecol Prog Ser 380:229-243

> Unsworth RK, Bell JJ, Smith DJ (2007) Tidal fish connectivity of reef and sea grass habitats in the Indo-Pacific. J Mar Biol Assoc UK 87:1287-1296

Vinueza LR, Branch GM, Branch ML, Bustamante RH (2006) Top-down herbivory and bottom-up El Niño effects on Galápagos rocky-shore communities. Ecol Monogr 76: 111-131

Vivien ML (1973) Contribution à la connaissance de l'éthologie alimentaire de l'ichtyofaune du platier interne des recifs coralliens de Tulear (Madagascar). Thethys (Suppl 5): 221-308

Willis TJ, Badalamenti F, Milazzo M (2006) Diel variability in counts of reef fishes and its implications for monitoring. J Exp Mar Biol Ecol 331:108-120

Submitted: May 11, 2010; Accepted: August 12, 2010

Proofs received from author(s): October 2, 2010 